\title{
Differentiation IN SEed MASS and SeEDling biomass allocation In Prosopis laEVIGata THROUGHOUT ITS DISTRIBUTION RANGE IN MEXICO IS ASSOCIATED TO WATER AVAILABILITY \\ LA DIFERENCIACIÓN EN LA MASA DE LA SEMILLA Y LA ASIGNACIÓN DE BIOMASA EN PLÁNTULAS de Prosopis laevigata a lo largo de su área de distribución en MÉXICO está asociada CON LA DISPONIBILIDAD DE AGUA
}

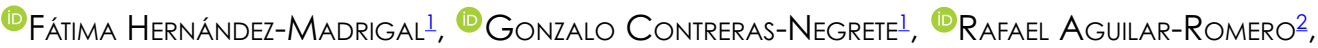 \\ - Fernando Pineda-García² and (1) Antonio González-Rodríguez ${ }_{-}^{*}$
}

\begin{abstract}
' Instituto de Investigaciones en Ecosistemas y Sustentabilidad, Universidad Nacional Autónoma de México, Morelia, México. ${ }^{2}$ Escuela Nacional de Estudios superiores, Unidad Morelia, Universidad Nacional Autónoma de México, Morelia, México. *Author for correspondence: agrodrig@iies.unam.mx
\end{abstract}

\begin{abstract}
Background: Seedling establishment depends on the quality of the seeds and environmental conditions. Differential biomass allocation in emergent seedlings probably constitutes a relevant adaptive response of populations along environmental gradients.

Questions: Are there differences in seed mass and biomass allocation in seedlings among Prosopis laevigata populations? Is this variation correlated with environmental variables?

Studied species: Prosopis laevigata (Humb. \& Bonpl. ex Willd.) M.C.Johnst (Fabaceae).

Study site and dates: Thirteen localities along the distribution of P. laevigata in México. From 2016 to 2020.

Methods: Seeds were collected from four or five mother trees per locality. Seed mass (SM) was obtained in ten seeds per mother and six functional traits indicative of biomass allocation were measured in the seedlings after 10 days of germination. Population mean values were obtained for the six traits plus SM and subjected to a principal component analysis (PCA). Population scores on the first two axis of the PCA were regressed against environmental variables from the collection localities using a stepwise regression model.

Results: Populations displayed functional variation congruent with alternative biomass allocation strategies. The conservative strategy was characterized by larger seeds and seedlings with denser tissues and a higher investment in root biomass, while the opposite characterized the acquisitive strategy. Actual evapotranspiration in May, isothermality and soil water content in February were environmental variables that significantly predicted population scores on the first two axes of the PCA.

Conclusion: Water availability gradients influence seed mass and seedling biomass allocation variation among $P$. laevigata populations.

Keywords: actual evapotranspiration, arid zones, functional traits, germination.

\section{Resumen}

Antecedentes: El establecimiento de las plántulas depende de la calidad de las semillas y las condiciones ambientales. El patrón de asignación de biomasa en plántulas recién emergidas es probablemente una adaptación relevante en gradientes ambientales.

Preguntas: ¿Existen diferencias en masa de la semilla y asignación de biomasa de plántulas entre poblaciones de Prosopis laevigata? ¿Se correlaciona esta variación con factores ambientales?

Especie de estudio: Prosopis laevigata (Humb. \& Bonpl. ex Willd.) M.C.Johnst (Fabaceae).

Sitio y años de estudio: Trece localidades de P. laevigata. 2016-2020.

Métodos: Se colectaron semillas de cinco árboles por localidad. Se determinó la masa (MS) en diez semillas por árbol y se midieron seis rasgos funcionales en plántulas de 10 días de edad. Las medias por población para los siete atributos se analizaron mediante componentes principales (PCA). Se hicieron regresiones multivariadas de los puntajes de las poblaciones en los dos primeros ejes del PCA contra las variables ambientales de las localidades.

Resultados: Las poblaciones desplegaron variación congruente con estrategias alternativas de asignación de biomasa. La estrategia conservativa mostró una alta biomasa de semilla y plántulas con tejidos densos y un mayor tejido radicular, mientras que el patrón opuesto caracterizó la estrategia adquisitiva. La evapotranspiración en mayo, la isotermalidad y el contenido de agua en el suelo en febrero fueron variables ambientales que predijeron los puntajes de las poblaciones en los dos primeros ejes del PCA.
\end{abstract}

Conclusión: Los gradientes de disponibilidad de agua influyen en la masa de las semillas y la asignación de biomasa en $P$. laevigata.

Palabras clave: evapotranspiración, germinación, rasgos funcionales, zonas áridas. 


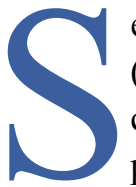

eedling establishment is preceded by key transition states such as germination and seedling emergence (Fenner \& Thompson 2005), whose success depends on the quality of the seeds and the environmental conditions (Lloret et al. 1999, Barak et al. 2018, Larson et al. 2015, Gardarin et al. 2016). During seed production, the environment experienced by mother plants may have a significant impact, since climatic factors such as temperature and precipitation, among others, can affect seed quality (Nemani et al. 2003). In turn, seed quality (i.e., seed mass) is correlated positively with rates of germination and seedling emergence (Moles \& Westoby 2004). Additionally, at the first stages of growth, seedlings are not capable of acquiring all necessary resources from the environment, so they depend almost exclusively on seed reserves for establishment (Nadeem et al. 2013).

Besides seed traits, plants have developed a multitude of adaptations to deal with the restrictions imposed by the environment. One of the main mechanisms is biomass allocation (Ackerly et al. 2000, Poorter et al. 2012, Donohue et al. 2010). It has been proposed that plants adapted to resource-rich environments but with high aboveground competition in general assign a higher biomass proportion to leaves and shoots, and species from resource-poor environments but with high below ground competition assign more biomass to roots (Tilman 1985).

Functional traits such as seed mass and patterns of biomass allocation influence seedling establishment and performance (Costa-Saura et al. 2016, Reich et al. 2003). Since functional traits are under selection by biotic and abiotic factors, spatial variation in these factors may translate into divergent selection driving differences in adaptations among populations (Petit \&Thompson 1998, Fajardo \& Piper 2011). Therefore, functional variation may be observed among populations and different strategies deployed to optimize resource use (Jung et al. 2010, Salazar et al. 2018). On one side, an acquisitive strategy, characterized by investment in photosynthetic tissues, allows fast growth under conditions of resource abundance; while a conservative strategy leaned towards the formation of dense tissues favors survival with little growth under resource limitation (Wright \&Westoby 1999, Reich et al. 2003). Trade-offs among traits underlay these strategies (Laughlin et al. 2018); therefore, describing functional variation and trade-offs among traits in response to different environmental conditions is crucial to understand plant adaptive evolution and their response to contemporary and projected climatic changes (Suding et al. 2008, Westoby 1998, Wright \&Westoby 1999).

In arid and semiarid environments, with frequent and prolonged dry periods, seedling survival after germination is a crucial step for plant establishment (Flores \& Jurado 1998, Flores et al. 2017, Pérez-Sánchez et al. 2011). Strategies such as the investment in large seeds and higher biomass allocation to root systems are related to survival (Adler et al. 2014). However, few studies have been conducted that examine variation in biomass allocation patterns in seedlings of arid-adapted trees across their entire distribution range. Species of genus Prosopis L. (Fabaceae) are dominant woody perennials in many arid and semiarid zones of the American continent (Fagg \& Stewart 1994). Their success in these environments is explained by a series of morphophysiological traits. The seed coat is thick and impermeable, what provides a mechanism of physical dormancy that is favorable in unpredictable environments (Villagra 1995). This coat, together with the nutritious mesocarp and the indehiscent pod, constitute adaptations to endozoic seed dispersal and contribute to seed survival and germination after ingestion (Campos \& Ojeda 1997). Seed germination is fast, taking 2-4 days to radicle emergence and 8-10 days to the appearance of the first leaves (Vilela \& Ravetta 2001). Seeds and seedlings are the most vulnerable stages to water stress; therefore, seed dispersal to favorable microsites is important. During their early growth seedlings rapidly develop an extensive root system for water acquisition (Flores Tena 1993).

Prosopis laevigata (Humb. \& Bonpl. ex Willd.) M.C. Johnst is the species of this genus with the widest distribution and highest ecological and economic importance in Mexico, being present in the arid zones of the north and center of the country as well as the semiarid areas in the south (Palacios et al. 2016, Rzedowski 1988). Prosopis laevigata is well adapted to extremely hot and dry environments throughout its distribution, but its wide distribution indicates that it is a species capable of establishing under variable conditions of temperature and humidity. Additionally, P. laevigata shows a good performance in poor soils and a high capacity of vegetative regeneration in agroforestry systems (Buendía-González et al. 2012, Pasiecznik et al. 2001, Ramírez-Arriaga et al. 2006).

The goal of this study was to evaluate variation in seed mass, germination percentage and biomass allocation traits in P. laevigata populations throughout most of the distribution of this species in México, determining trade-offs that 
guide functional strategies of the seedling emergence, and to understand how environmental factors may explain this intraspecific variation. The specific questions were 1) Are there intraspecific differences in seed mass, germination percentage and seedling biomass allocation traits among $P$. laevigata populations along the distribution of the species in México? 2) Are there trade-offs among biomass allocation traits in P. laevigata populations? 3) Is the variation in seed mass, germination percentage and biomass allocation in $P$. laevigata populations correlated with environmental variables? Given the broad distribution and heterogeneous environments occupied by P. laevigata in Mexico, we expected significant functional variation among populations, with trade-offs among traits guiding differential strategies of resource acquisition in correlation with environmental factors.

\section{Materials and methods}

Study species. Prosopis laevigata (Fabaceae, Mimosoideae) is a tree or shrub up to $12 \mathrm{~m}$ in height distributed in the arid and semiarid zones of several physiographic regions of Mexico, including the Oaxaca Central Valleys, Tehuacán-Cuicatlán Valley, Balsas Depression, Trans-Mexican Volcanic Belt, Mexican Altiplano and Tamaulipas Plains (Calderón \& Rzedowski 2001, Rzedowski 1988, Palacios 2006). The species is mainly pollinated by hymenopterans and is self-compatible with percentages of self-fertilization between 65-85\% (Galindo Almanza et al. 1992). The seeds are dispersed by mammals and water currents (Campos \& Ojeda 1997, De Noir et al. 2002, Pasiecznik et al. 2001). Detailed phenological studies for $P$. laevigata are lacking, but our own observations indicate that flowering of the species occurs in February and March, seed maturation starts in May and seed dispersal takes place in July and August (Pérez-Sánchez et al. 2011, Galindo Almanza et al. 1992).

Seed sampling and germination. We used seeds of Prosopis laevigata from 13 populations encompassing a large portion of the distribution of the species in México (Table 1, Figure 1) and representative of the environmental gradient experienced by the species. Vegetation type was xerophytic scrub in most cases, even though in some sites, particularly southern ones, tropical dry forest vegetation was present (Rzedowski 1988, Palacios 2006). The mean annual temperature in sampled sites varies between 15 and $24^{\circ} \mathrm{C}$ and annual precipitation between 360 and $752 \mathrm{~mm}$ (Table 1).

At each locality, fruits from four or five mother plants were collected according to their availability. In northern localities, where in some cases contact zones occur between P. laevigata and P. glandulosa, we verified that sampled individuals showed distinctive features, such as the smaller and darker leaflets and the more constrained and purplish pods in P. laevigata in comparison to the yellow pods of $P$. glandulosa (Calderón \& Rzedowski 2001, Palacios 2006). Sampled pods were in all cases taken directly from the mother tree (not from the ground) and were ripe and without signs of damage by pathogens or herbivores. Sampling at all sites was performed during the same season (July of 2016). The seeds were extracted from the pods for subsequent washing and disinfection with $5 \%$ sodium hypochlorite, and then stored at room temperature in transparent vials with $5 \mathrm{~g}$ of commercial fungicide until used. It is known that under these conditions, Prosopis seeds can remain viable for at least a decade (Pasiecznik et al. 2001).

A total of 600 seeds $(10$ seeds $\times$ mother tree $\times$ population) were germinated in June of 2019. Firstly, seeds were individually weighed to determine seed mass (SM) and then scarified mechanically using sandpaper. Scarification is necessary since physical dormancy has been reported for the seeds of Prosopis species. Under natural conditions, dormancy is broken through endozoochory or seed entrainment by watercourses. From an experimental perspective, different chemical compounds (i.e., sulfuric acid, hydrochloric acid, sodium hydroxide) as well as hot water treatments and mechanical scarification by sandpaper have been tested (Ortega-Baes et al. 2002, Miranda et al. 2011, Majd et al. 2013). Consistently, mechanical scarification with sandpaper has shown satisfactory results in breaking dormancy (Ortega-Baes et al. 2002). Therefore, we decided to use this type of scarification because of the economy, ease, and safety of its handling in relation to chemical compounds. Afterwards, seeds were sown in groups of three in Petri dishes layered with a double sheet of filter paper (Whatman No. 1). Dishes were placed in germination chambers (ICP-19 LUMISTELL) using a 12-h photoperiod and at a constant temperature of $30^{\circ} \mathrm{C}$, known to be optimal 
for germination of this and other Prosopis species (Cony \& Trione 1996), Contreras-Negrete et al. 2021b). The filter paper was maintained continuously soaked by adding $3 \mathrm{~mL}$ of distilled water every third day and the position of the Petri dishes within the chamber was shifted regularly. Seeds were checked once per day and recorded as germinated once the radicle reached $2 \mathrm{~mm}$, following Cony \& Trione (1998).

Table 1. Geographical and environmental data for 13 collection locations of Prosopis laevigata seeds, germination percentage and number of seedlings analyzed. MAT = Mean Annual Temperature; AP = Annual Precipitation.

\begin{tabular}{|c|c|c|c|c|c|c|c|c|c|c|}
\hline Number & Population & Code & State & Latitude & Longitude & $\begin{array}{c}\text { Elevation } \\
\text { (masl) }\end{array}$ & $\begin{array}{c}\text { MAT } \\
\left({ }^{\circ} \mathbf{C}\right)\end{array}$ & $\mathbf{A P}(\mathbf{m m})$ & $\begin{array}{c}\text { Germina- } \\
\text { tion per- } \\
\text { centage }\end{array}$ & $\begin{array}{l}\text { Seedlings } \\
\text { analyzed }\end{array}$ \\
\hline 1 & Santa María & SMA & Oaxaca & 17.892 & -97.822 & 1,905 & 19.1 & 687 & 18 & 5 \\
\hline 2 & Indaparapeo & IND & Michoacán & 19.794 & -100.968 & 1,908 & 17.7 & 753 & 68 & 23 \\
\hline 3 & Sayula & SY & Jalisco & 19.926 & -103.528 & 1,350 & 20.6 & 627 & 62.5 & 21 \\
\hline 4 & Cuitzeo & CUI & Michoacán & 19.961 & -101.202 & 2,033 & 17.9 & 716 & 60 & 8 \\
\hline 5 & San Pedro T & $\mathrm{SP}$ & Jalisco & 20.221 & -103.395 & 1,538 & 19.2 & 699 & 55 & 12 \\
\hline 6 & Novillero & NOV & Guanajuato & 20.388 & -101.591 & 1,718 & 19.2 & 682 & 48 & 9 \\
\hline 7 & Ixmiquilpan & IXM & Hidalgo & 20.460 & -99.339 & 1,852 & 17.1 & 361 & 42.5 & 10 \\
\hline 8 & $\begin{array}{l}\text { Peña de } \\
\text { Bernal }\end{array}$ & PÑ & Querétaro & 20.745 & -99.947 & 2,125 & 15.8 & 451 & 64 & 17 \\
\hline 9 & $\begin{array}{l}\text { Lagos } \\
\text { Moreno }\end{array}$ & LM & Jalisco & 21.369 & -101.962 & 1,930 & 17.8 & 591 & 67.5 & 14 \\
\hline 10 & Charco B & $\mathrm{HM}$ & San Luis P & 22.550 & -99.805 & 1,022 & 20.3 & 383 & 70 & 14 \\
\hline 11 & $\begin{array}{l}\text { Villa de } \\
\text { Arista }\end{array}$ & VA & San Luis P & 22.643 & -100.845 & 1,618 & 17.9 & 400 & 76 & 19 \\
\hline 12 & Huizachal & HUI & Tamaulipas & 23.588 & -99.224 & 853 & 20.7 & 470 & 90 & 15 \\
\hline 13 & Matehuala & MAT & San Luis P & 23.630 & -100.640 & 1,925 & 18.7 & 488 & 95 & 23 \\
\hline
\end{tabular}

Measurement of functional traits. After 10 days of the initiation of the experiment, we performed six standardized measurements of functional traits in the seedlings (see Table 2 for definition and biological significance of each trait) (Pérez-Harguindeguy et al. 2013). The length of the aerial part (LA) and the length of the root (LR) were measured with a Mitutoyo Absolute digital caliper (model 500-172-20) with a $0.01 \mathrm{~mm}$ precision. Seedlings were then separated into cotyledons, root, stem and leaves and the fresh weight of each of these plant parts was determined separately with an analytical balance. The area of the fresh cotyledons (AC) was estimated from scanned images using the software Image $\mathrm{J}$. Afterwards, plant parts were placed in paper bags and oven dried at $70{ }^{\circ} \mathrm{C}$ for $72 \mathrm{~h}$ and subsequently their dry weight was measured. From these data, we calculated specific cotyledon area (SCA) as the ratio between AC and cotyledon dry mass. Leaf dry matter content (LDMC) was estimated as the ratio of the leaf dry weight to leaf fresh weight. Similarly, root dry matter content (RDMC) was estimated as the ratio of root dry weight to root fresh weight. Stem volume was obtained by the water displacement method (Pineda-García et al. 2011), and then used to calculate stem density (SD) as the ratio of the stem volume to stem dry weight. Root/shoot ratio $(\mathrm{R} / \mathrm{S})$ was obtained as the ratio of the aerial part biomass to the root biomass. Finally, the seedling maximum length (Lmax) was determined as the sum of LA and LR. 


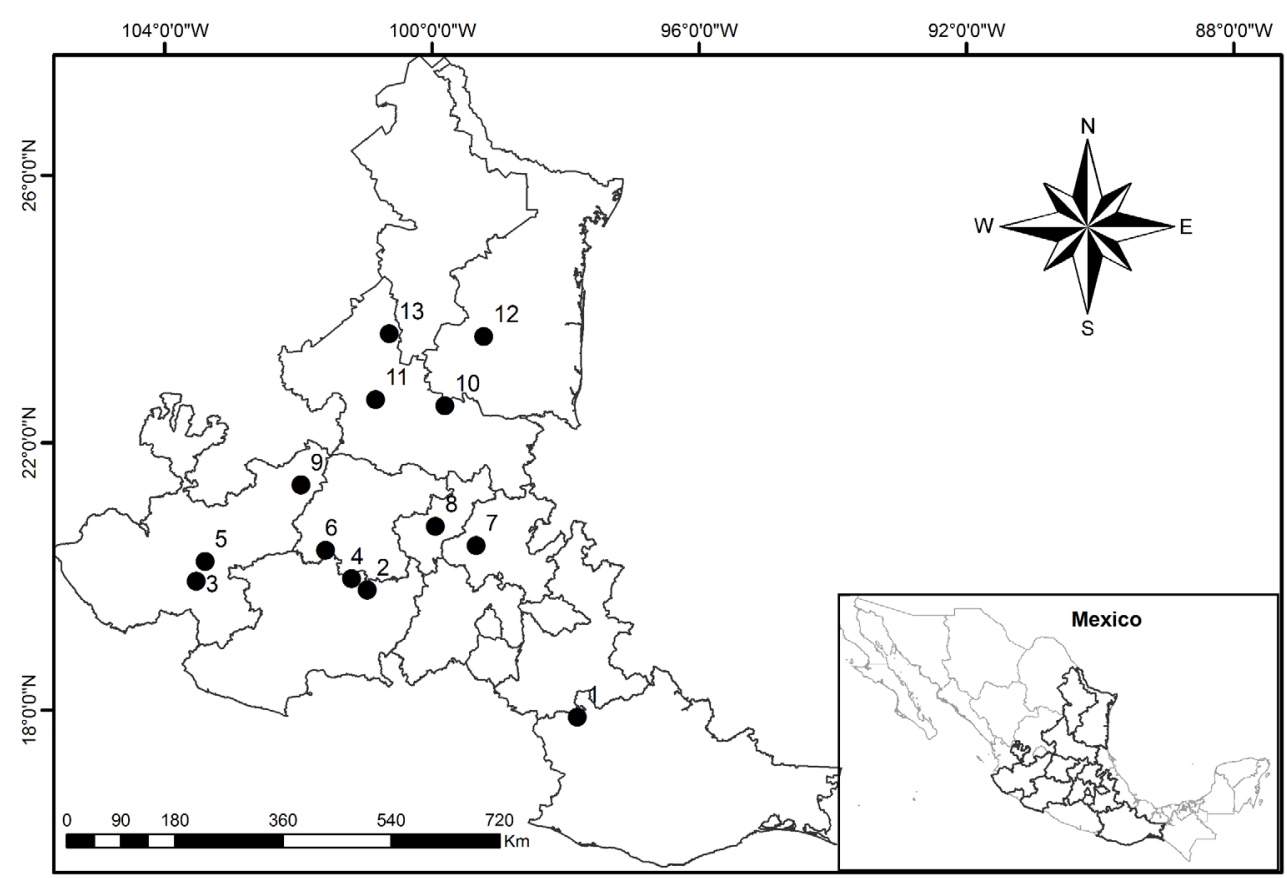

Figure 1. Geographical location of Prosopis laevigata populations sampled in this study. Dots and number indicate the populations. See Table 1 for population details.

Table 2. List of functional traits and their corresponding abbreviations, units, obtained from and biological significance.

\begin{tabular}{|c|c|c|c|c|}
\hline Functional trait & Abbreviation & Units & Obtained from & Biological significance \\
\hline $\begin{array}{l}\text { Leaf dry mat- } \\
\text { ter content }\end{array}$ & LDMC & $\mathrm{mg} \mathrm{g}^{-1}$ & $\begin{array}{l}\text { Ratio of the leaves dry weight } \\
\text { to the leaves fresh weight }\end{array}$ & $\begin{array}{l}\text { Positively correlated with rela- } \\
\text { tive growth rate }{ }^{1}\end{array}$ \\
\hline $\begin{array}{l}\text { Maximum } \\
\text { length }\end{array}$ & Lmax & $\mathrm{mm}$ & $\begin{array}{l}\text { Aerial length plus the root } \\
\text { length }\end{array}$ & Growth rate, competitive vigor ${ }^{1}$ \\
\hline $\begin{array}{l}\text { Root dry mat- } \\
\text { ter content }\end{array}$ & $\mathrm{RDMC}$ & $\mathrm{mg} \mathrm{g}^{-1}$ & $\begin{array}{l}\text { Ratio of the root dry weight to } \\
\text { the root fresh weight }\end{array}$ & $\begin{array}{l}\text { Efficiency in getting under- } \\
\text { ground resources }{ }^{1}\end{array}$ \\
\hline $\begin{array}{l}\text { Root/shoot } \\
\text { ratio }\end{array}$ & $\mathrm{R} / \mathrm{S}$ & Unitless & $\begin{array}{l}\text { Ratio of the belowground } \\
\text { biomass to the aboveground } \\
\text { biomass }\end{array}$ & $\begin{array}{l}\text { Compensation in the limitation } \\
\text { of resources, survival and com- } \\
\text { petition }^{1}\end{array}$ \\
\hline Seed mass & $\mathrm{SM}$ & $\mathrm{mg}$ & Weight of the seed & $\begin{array}{l}\text { Resources allocated for germi- } \\
\text { nation and seedling }{ }^{1}\end{array}$ \\
\hline $\begin{array}{l}\text { Specific coty- } \\
\text { ledon area }\end{array}$ & SCA & $\mathrm{mm}^{2} \mathrm{mg}^{-1}$ & $\begin{array}{l}\text { Ratio of the average area of the } \\
\text { cotyledons to the average dry } \\
\text { weight of the cotyledons }\end{array}$ & $\begin{array}{l}\text { Reserves allocated for early } \\
\text { growth and for beginning of } \\
\text { photosynthesis }{ }^{2}\end{array}$ \\
\hline Stem density & SD & $\mathrm{mg} \mathrm{mm}^{-3}$ & $\begin{array}{l}\text { Ratio of the stem volume to dry } \\
\text { weight }\end{array}$ & $\begin{array}{l}\text { Stability, defense, architecture, } \\
\text { hydraulic characteristics, and } \\
\text { potential growth of plants }^{1}\end{array}$ \\
\hline
\end{tabular}

${ }^{1}$ Pérez-Harguindeguy et al. (2013).

${ }^{2}$ Gogosz \& Boeger (2019). 
Environmental variables. Nineteen bioclimatic variables were extracted for the 13 collection sites from high-resolution monthly climate surfaces of the study area, available at https://github.com/AngelaCrow/variables-bioclimatica; (Cuervo-Robayo et al. 2014), using GIS ArcView ver. 3.3 (ESRI 1999). We also considered 24 variables describing monthly values of actual evapotranspiration and soil water content (https://figshare.com/articles/Global_High-Resolution_Soil Water_Balance/7707605/3); see Trabucco \& Zomer (2010) for more details. To avoid redundancy among variables in subsequent analyses, highly correlated variables were discarded through a pairwise correlation test among the 43 variables, eliminating the more specific variable for each pair of variables with $r \geq 0.9$ (i.e., preferentially discarding mean temperature of the warmest quarter over mean annual temperature). This analysis was conducted using the JMP v11.0.0 (SAS Institute Inc., Cary, NC, USA) statistical package. After this procedure, 14 environmental variables were considered in the analysis (Table 3). Finally, latitude, longitude and elevation were used as geographic variables.

Table 3. Bioclimatic, soil and geographic variables included in this study for Prosopis laevigata populations.

\begin{tabular}{ll}
\hline $\begin{array}{l}\text { Bioclimatic } \\
\text { variables }\end{array}$ & \\
\hline BIO1 & Annual Mean Temperature \\
BIO3 & Isothermality \\
BIO4 & Temperature Seasonality \\
BIO5 & Max Temperature of Warmest Month \\
BIO7 & Temperature Annual Range \\
BIO9 & Mean Temperature of Driest Quarter \\
BIO12 & Annual Precipitation \\
BIO14 & Precipitation of Driest Month \\
BIO15 & Precipitation Seasonality \\
BIO18 & Precipitation of Warmest Quarter \\
BIO19 & Precipitation of Coldest Quarter \\
\hline Geographic & \\
variables & \\
\hline Latitude & \\
Longitude & \\
Elevation & \\
\hline Water availabilty \\
variables & \\
\hline SW2 & Soil Water Content on February \\
SW3 & Soil Water Content on March \\
SW4 & Soil Water Content on April \\
AET5 & Actual Evapo Transpiration factor on May \\
AET6 & Actual Evapo Transpiration factor on June \\
\hline AET9 & Actual EvapoTranspiration factor on September \\
\hline
\end{tabular}

Data analysis. Simple linear regressions were performed to evaluate the effect of seed mass (mean values per population) on the percentage of germinated seeds. Regressions of this response variable were also conducted on geographic and environmental variables of the collection localities. For seed mass and the six seedling functional traits, data normality was tested, and values were log-transformed if necessary. One-way analyses of variance (ANOVA) were conducted to test for differences among populations for the seven evaluated traits. 
Mean values of the seven traits were calculated for each population and then pairwise correlation analyses were performed among all traits to identify patterns of coordination among these functional variables across populations. To visualize these patterns and to observe potential differences in the strategy of biomass allocation among populations, we also conducted a principal components analysis (PCA). To assess whether these patterns are related to environmental variables, we performed a stepwise multiple regression analysis of the population scores on the first two principal components (PC1 and PC2, response variables) and the selected climatic, soil water balance and geographic variables of the collection localities (independent variables; Table 3), using the forward variable selection procedure and the probability to enter set to 0.05 . The best models were selected on the basis of the corrected Akaike information criterion (AICc) (Akaike 1974). All analyses were performed in JMP v. 11.0.0 (SAS Institute Inc., Cary, $\mathrm{NC}$, USA) statistical package.

\section{Results}

Germination percentages between 18 and $95 \%$ were observed in the populations (Table 1), with lower percentages in southern populations and higher in northern populations (i.e., increased latitudinally; Figure 2), without a significant effect of seed mass or other geographic or environmental variables at the collection localities. Due to these differences in germination percentage, the number of analyzed seedlings per population varied between five and 23 (Table 1). The one-way analyses of variance revealed that the studied populations differed significantly in the seven evaluated traits (Table 4; Table S1).

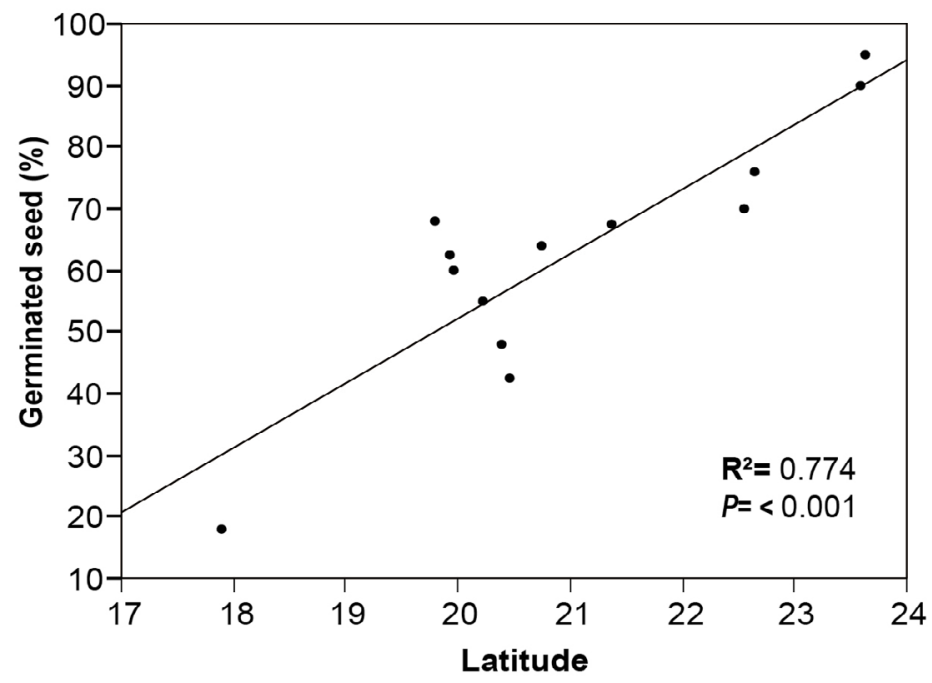

Figure 2. Linear regression of the percentage of seeds germinated and latitude of the collection localities.

The pairwise correlation analyses between the measured functional traits indicated significant positive correlations between seed mass and stem density; root dry matter content and the root/shoot ratio; maximum length and specific cotyledon area; and root dry matter content and stem density (Table 5). In turn, negative correlations were observed between seed mass and leaf dry matter content; root/shoot ratio and leaf dry matter content; and leaf dry matter content and stem density (Table 5).

The first two principal components of the PCA jointly explained $78.3 \%(49.4$ and $28.9 \%$ for the PC1 and PC2, respectively) (Table 6). The variables with the highest loadings on the PC1 were seed mass, stem density and the root dry mass content, while for the PC2 the variables with the highest loadings were maximum length, 
specific cotyledon area and root/shoot ratio (Table 6). In the PCA plot (igure 3), it can be observed that trait combinations associated to conservative resource use are indicated by positive values of the PC1 (larger seeds and seedlings with denser tissues and a higher investment in the development of the root system). In contrast, negative values on the PC1 indicate an acquisitive strategy (higher investment in aerial tissues). Positive values on the PC2 are also indicative of this strategy (Table 6, Figure 3). The distribution of P. laevigata populations in this plot indicated that the most differentiated population was number 12 (Huizachal, Tamaulipas) which showed the lowest score on the PC1 (Figure 3). In contrast, the highest score on the PC1 was observed for population 8 (Peña de Bernal, Querétaro), followed by population 3 (Sayula, Jalisco). On the PC2, the highest and lowest scores were observed for populations 13 (Matehuala, San Luis Potosí) and 2 (Indaparapeo, Michoacán), respectively (igure 3 ).

Table 4. Results of the one-way ANOVA testing for differences among Prosopis laevigata populations in the seven traits evaluated.

\begin{tabular}{lccccc}
\hline \multicolumn{1}{c}{ Trait } & SS & df & MS & F & $p$ \\
\hline Leaf dry matter content & 7.7264 & 12 & 0.6438 & 3.043 & 0.0006 \\
Maximum length & 0.9098 & 12 & 0.0758 & 3.247 & 0.0003 \\
Root dry matter content & 19.531 & 12 & 1.6276 & 8.212 & $<0.0001$ \\
Root/shoot ratio & 18.887 & 12 & 1.5739 & 8.063 & $<0.0001$ \\
Seed mass & 0.0161 & 12 & 0.0013 & 26.554 & $<0.0001$ \\
Specific cotyledon area & 0.5523 & 12 & 0.0460 & 1.921 & 0.0346 \\
Stem density & 6.8694 & 12 & 0.5724 & 6.034 & $<0.0001$ \\
\hline
\end{tabular}

Table 5. Pairwise Pearson's correlation coefficients for seven seed and seedling functional traits in Prosopis laevigata populations. Significant correlations $(P<0.05)$ are in bold. See Table 2 for functional trait abbreviations.

\begin{tabular}{ccccccc}
\hline $\begin{array}{c}\text { Functional } \\
\text { Trait }\end{array}$ & LDMC & Lmax & RDMC & R/S & SM & SCA \\
\hline Lmax & -0.2457 & & & & \\
RDMC & -0.5219 & 0.1569 & & & \\
R/S & $\mathbf{- 0 . 5 6 4 1}$ & 0.3324 & $\mathbf{0 . 8 9 7 5}$ & & & \\
SM & $\mathbf{- 0 . 7 6 9 8}$ & -0.16 & 0.5189 & 0.4022 & & \\
SCA & 0.0546 & $\mathbf{0 . 6 7 9 1}$ & -0.0671 & 0.0989 & -0.4765 & \\
SD & $\mathbf{- 0 . 6 1 4 5}$ & 0.0812 & $\mathbf{0 . 5 6 6 3}$ & 0.3079 & $\mathbf{0 . 7 8 4 4}$ & -0.3294 \\
\hline
\end{tabular}

The stepwise multiple regression analyses indicated in the case of the PC1 a significant effect of actual evapotranspiration in May (negative relationship) and isothermality (positive relationship) on this variable (Table 7). However, the effect of isothermality is no longer significant if population 12 is removed from the analysis. For the PC2, the only variable with a significant effect (negative relationship) was soil water content in February (Table 7). The bivariate relationships between PC1 and PC2 and the significant predictor variables are shown in Figure 4. 
Differentiation in seedling biomass allocation in Prosopis laevigata

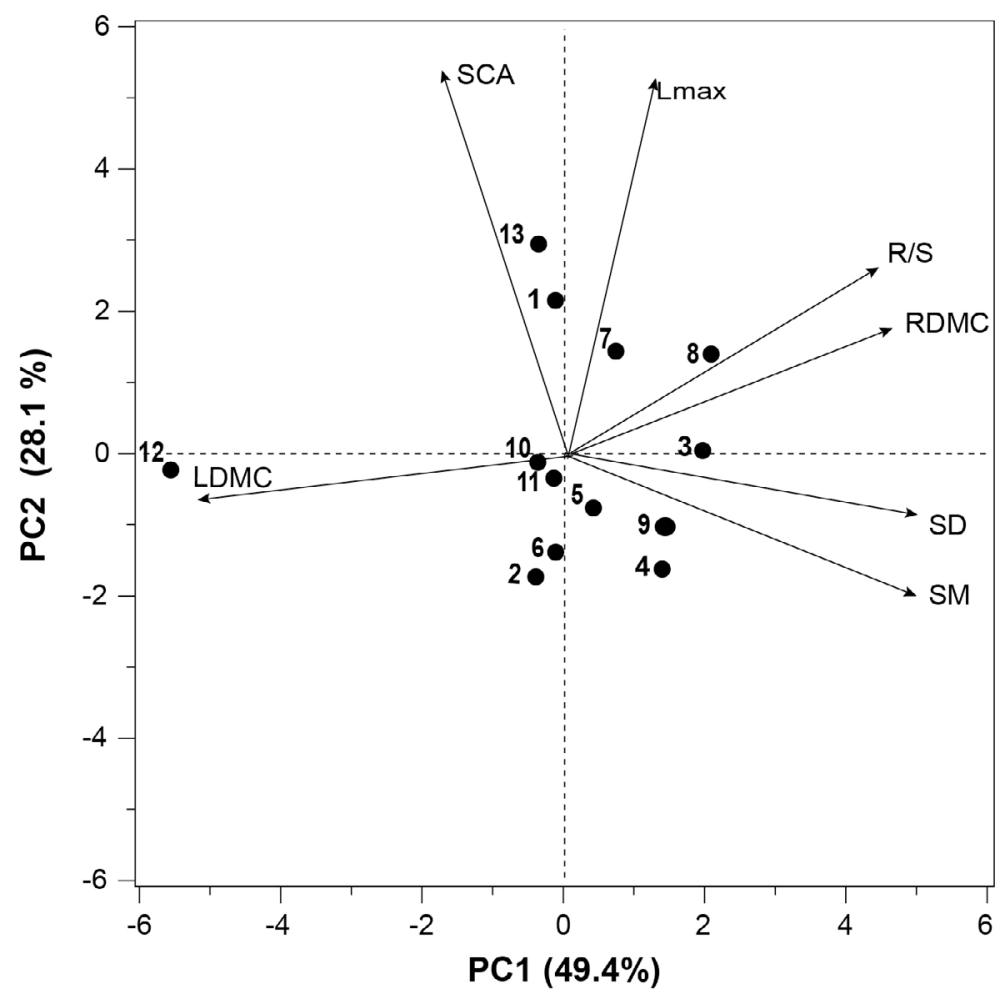

Figure 3. Biplot of the two first axes from a principal component analysis (PCA) for the seven traits evaluated. Dots with numbers indicate the 13 sampled populations of Prosopis laevigata. See Table 1 for population details.

Table 6. Eigenvector scores of functional traits in two main PCA axes. The highest eigenvector scores for each PCA axis are indicated in bold. Values in parentheses indicate variance accounted for by each axis. See Table 2 for abbreviation of functional traits.

\begin{tabular}{lcc}
\hline $\begin{array}{l}\text { Functional } \\
\text { trait }\end{array}$ & PC1 (49.4\%) & PC2 (28.9\%) \\
\hline LDMC & $\mathbf{- 0 . 4 5 3 1 7}$ & -0.07514 \\
Lmax & 0.0761 & $\mathbf{0 . 6 2 2 1 5}$ \\
RDMC & $\mathbf{0 . 4 5 0 6 2}$ & 0.15013 \\
R/S & 0.40398 & $\mathbf{0 . 3 0 3 4 8}$ \\
SM & $\mathbf{0 . 4 6 3 3 1}$ & -0.26626 \\
SCA & -0.13338 & $\mathbf{0 . 6 3 2 6 7}$ \\
SD & $\mathbf{0 . 4 3 6 0 5}$ & -0.14655 \\
\hline
\end{tabular}


A)

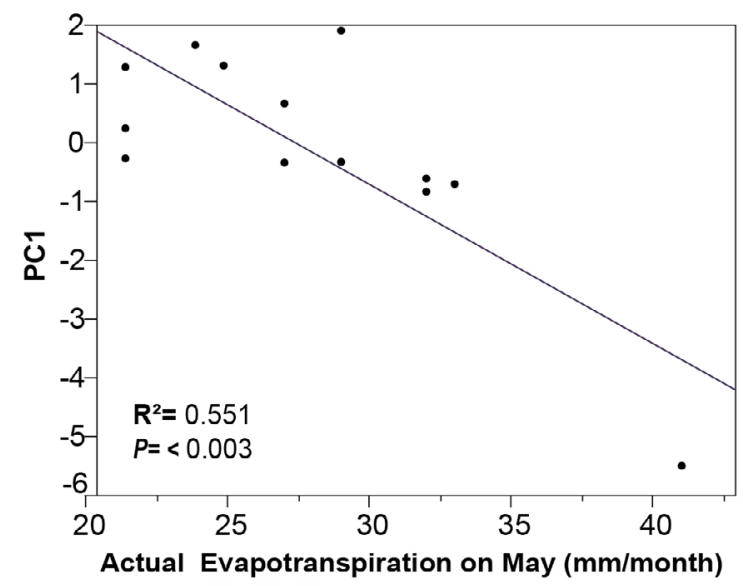

B)

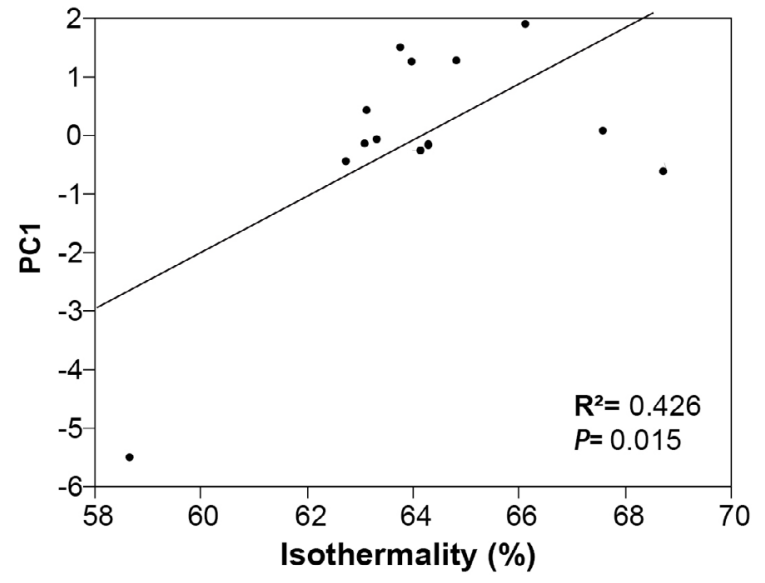

C)

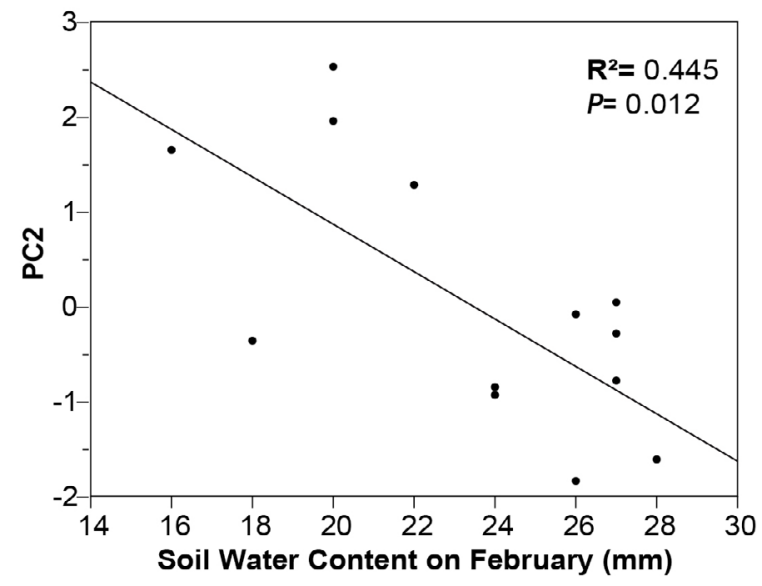

Figure 4. Bivariate regressions of A) Population scores on the first axis of the PCA on actual evapotranspiration on May, B) Population scores on the first axis of the PCA on isothermality and C) Population scores on the second axis of the PCA on soil water content in February. 
Table 7. Results of the multiple regression analysis of the population scores on the two first axes of a principal components analysis of Prosopis laevigata seed mass and seedling functional trait variation and environmental and geographic variables of the collection localities.

\begin{tabular}{ccccccc}
\hline Response variable & Term & Estimate & $\begin{array}{c}\text { Standard } \\
\text { Error }\end{array}$ & $\boldsymbol{t}$ & $\boldsymbol{P}$ & $\boldsymbol{R}^{2}$ (P model) \\
& Intercept & -17.86 & 7.94 & -2.25 & 0.048 & 0.77 \\
PC1 & AET5 & -0.20 & 0.05 & -3.93 & 0.0028 & \\
& Isothermality & 0.36 & 0.12 & 3.14 & 0.0105 & $(0.0006)$ \\
& & & & & & \\
& Intercept & 5.61 & 1.90 & 2.95 & 0.0134 & 0.47 \\
& SWC2 & -0.24 & 0.08 & -2.98 & 0.0125 & \\
& & & & & & $(0.0125)$ \\
\hline
\end{tabular}

\section{Discussion}

In this study, we tested for among-population variation in seed mass and biomass allocation in seedlings of $P$. laevigata. Furthermore, we expected this variation to represent differential strategies of resources acquisition, guided by trade-offs among traits, and correlated with local conditions across the environmental gradient encompassed by the distribution of the species. Describing biomass allocation patterns and the underlying environmental factors that shape them is informative about the ecological strategies of species (Westoby 1998). For this reason, we analyzed functional variation and coordination among traits that define biomass allocation strategies, from the seed to the seedling emergence stages across populations of $P$. laevigata throughout most of the distribution of the species in Mexico. Since seeds were treated equally and germinated in a common environment, it is probable that the observed variation has a genetic component.

The results contribute to the understanding of the adaptive mechanisms that favor successful establishment of $P$. laevigata along the varying environmental conditions of the arid and semiarid zones of the south, center and north of Mexico. We found that in populations with smaller seeds, seedlings are characterized by a higher investment in photosynthetic tissues and growth of the aerial parts. In contrast, the seedlings in populations with larger seeds have denser tissues and a larger relative investment in the root system, favoring resource conservation and survival in more resource-poor environments, as has been concluded from generalizations encompassing hundreds of plant species including a global range of biomes and growth forms (Lambers \& Poorter 1992, Adler et al. 2014, Murray et al. 2004). These distinct strategies are probably adaptive under the variable conditions across the distribution of P. laevigata and bring about trade-offs among traits, since the enhancement of one trait usually has costs on other traits (Reich 2014).

The PCA allowed to observe these associations among traits in detail (Figure 3). The variables that had higher loadings on the PC1 were seed mass, stem density and root dry mass content. Positive values on this axis indicated seedlings with dense tissues that emerged from larger seeds and with a higher investment in root development, while negative values indicated the opposite pattern. Therefore, the first axis was mainly driven by the association of tissue density and seed mass, noting the resource investment conflict between above and belowground traits. On one side of the axis, the group of populations coming from heavier seeds produced seedlings with denser root and stem. In contrast, populations with lighter seeds had seedlings with denser leaves. Overall, tissue density is an indicator of plant resistance to abiotic and biotic stress (Niinemets 2001, Méndez-Alonzo et al. 2012, Pineda-García et al. 2016, Markesteijn \& Poorter 2009). Particularly, a high root and stem density is a result of a dense xylem. A higher stem density is determined by vessels with reinforced walls and/or a higher proportion of fibers, which are more resistant to embolism formation during soil drought (Hacke et al. 2001, Jacobsen et al. 2007, Pineda-García et al. 2016). Contrary, leaves of high density usually have lower nitrogen and phosphorus concentration and lower gas exchange 
rates, but are more resistant to water stress (Niinemets 2001, Pineda-García et al. 2016). Both extremes of this axis would be successful under environments that experience water stress. However, the populations with denser root and stem and, therefore, more resistant to embolism, would survive more frequent and intense soil drought. In contrast, populations with dense leaves would be better adapted to environments with a higher air vapor pressure deficit.

For the PC2, the variables with the higher loadings were maximum length, specific cotyledon area and root/shoot ratio, with positive values on the PC2 indicating high relative investment in aerial and photosynthetic tissues. Therefore, the second axis reflects a conflict of resource allocation to produce aerial tissues. On one extreme of the axis were the populations with longer seedlings and with cotyledons of large specific leaf area. Large specific leaf area results from large carbon capture area per unit of biomass invested in the leaf construction, which is related with higher photosynthetic and growth rates (Reich et al. 1998, Reich et al. 1999, Pineda-García et al. 2016, Wright \& Westoby 1999). In sum, this suggests this group of populations had a higher canopy dominance and a resource acquisitive strategy and thus, would be more adapted to habitats with low water stress. On the other side, the other group of populations invested more biomass to stem but were shorter and with cotyledons with lower specific leaf area, limiting their capacity for resource capture. Thus, both PC1 and PC2 suggest a conflict of resource allocation at the above and belowground portions to generate either resistant or acquisitive organs. In addition, this pattern of allocation could be promoted by different aboveground or belowground environmental pressures experienced by populations in the field.

Interestingly, these patterns displayed by the populations did not follow a clear geographical pattern but were instead significantly explained by environmental variables. For the PC1, we detected a high negative correlation with the actual evapotranspiration in May, indicating that emergent $P$. laevigata seedlings from sites with lower actual evapotranspiration in this month (and thus less water availability) have traits associated with a more conservative strategy. In turn, the positive correlation of the PC1 with isothermality suggests that in localities where temperature is more constant throughout the year (i.e., higher isothermality), the emergent $P$. laevigata seedlings have traits indicative of a more conservative strategy. However, the relationship between PC1 and isothermality is no longer significant if population 12 is removed from the analysis and thus must be taken with caution. On the other hand, PC2 showed a negative correlation with the soil water content in February, indicating that in sites with higher soil water content in this month, the emergent $P$. laevigata seedlings have a lower maximum height, root/shoot ratio and specific cotyledon area (i.e., traits that indicate a conservative strategy).

In general, these results suggest that the observed intraspecific variation in seed mass and seedling functional traits may be important for adaptation to water availability during the crucial stages of seed development germination and seedling emergence and establishment. The reproductive phenology of $P$. laevigata is characterized by flowering in the late winter (February and early March), initiation of seed maturation in May, and seed dispersal in the summer (July and August) (Galindo Almanza et al. 1992, Pérez-Sánchez et al. 2011). It is likely that seeds remain dormant in the seedbank for several months and germinate with the summer rains of the next year. In the collection localities, the higher number of seedlings is found from July to September (G. Contreras-Negrete, personal observation). Therefore, the main pattern found is that populations of $P$. laevigata in areas where water availability is higher during these phenological events follow a more acquisitive strategy, while populations in sites with less water availability follow a more conservative strategy. The impact of this variation on the population dynamics, particularly on early development phases of wild populations of $P$. laevigata, which face unpredictable conditions and climate change, requires more detailed studies in the future.

Previous studies conducted on adult trees or seedlings of other Prosopis species inhabiting hyper arid deserts, such as P. caldenia, P. glandulosa, P. flexuosa and P. pallida (Ansley et al. 2007, Guevara et al. 2010, de Villalobos \& Peláez 2015, Salazar et al. 2019) have revealed a significant capacity for phenotypic adjustment through plastic responses of biomass allocation in response to water availability in mesquites. The results here presented suggest that besides phenotypic plasticity, potentially genetically determined functional differences among populations may be very important for survival during the very crucial stages of germination and seedling emergence, perhaps before plastic responses can come into play.

Interestingly, the variables that we identified as having the most significant effect on functional variation were 
related to soil water availability and not to precipitation, in concordance with previous results indicating that precipitation is a poor predictor of plant traits because of its weak link with water availability for plants (Moles et al. 2014), and this may be particularly the case in arid and semiarid ecosystems. On the other hand, a previous ecological niche model for P. laevigata (Palacios et al. 2016) suggested that temperature seasonality is the most important climatic variable to explain the distribution of the species. In this study, we detected a possible association between the PC1 of the functional variation with isothermality (even though determined by a single population), which is a variable that is generally highly correlated with temperature seasonality. These results suggest a role of the patterns of temporal temperature fluctuations on the adaptation of P. laevigata to the environment. Additionally, we suggest that including water availability variables into the niche models of species from arid or semiarid zones such as $P$. laevigata could significantly increase the accuracy of the predictions.

Finally, another noticeable pattern that we found in this study was the significant latitudinal increase in seed germination percentage in $P$. laevigata populations. This result is similar to what has been documented in more detailed experiments of germination response to temperature, salinity and water stress for the same populations of $P$. laevigata (Contreras-Negrete et al. 2021b). In our case, the variation in germination percentage was not significantly correlated with any of the environmental variables considered and neither with seed mass. Latitudinal variations in germination percentage have also been found in other Mexican tree species, such as Quercus rugosa (Llanderal-Mendoza et al. 2017). These authors point out a significant positive correlation of germination percentage with seed mass but the association of these two variables with latitude was negative, and a significant influence of climatic variables was detected. In the case of P. laevigata it is possible that the lower germination percentage in southern populations is due to genetic factors, since these populations show considerably reduced genetic variation in comparison to northern ones, probably related with an also lower population density (Contreras-Negrete et al. 2021a). Therefore, future studies could be aimed at examining if southern population are experiencing inbreeding depression or other genetically based fitness attrition processes.

In conclusion, we have documented variation in seed mass and biomass allocation in seedlings among populations of $P$. laevigata along a large part of the distribution of the species. Significant associations were observed among the functional traits analyzed, defining the segregation of populations along the conservative/acquisitive strategies continuum. We found that evapotranspiration and soil water content at specific times of the year, along with isothermality, are probably the climatic variables that best explain the observed variation.

\section{Supplementary material}

Supplemental data for this article can be accessed here: https://doi.org/10.17129/botsci.2846

\section{Acknowledgements}

The authors thank Martin de La Torre for help in setting the germination experiment and measurement of seedling functional traits. FHM thanks a postdoctoral scholarship from DGAPA-UNAM. Funding for this study was provided by grant IA203221 from UNAM-DGAPA-PAPIIT to FPG and by IIES-PO to AGR. The comments by two anonymous reviewers and Teresa Terrazas greatly contributed to improve the previous versions of this manuscript.

\section{Literature cited}

Ackerly DD, Dudley SA, Sultan SE, Schmitt J, Coleman JS, Linder CR, Sandquist DR, Geber MA, Evans AS, Dawson TE, Lechowicz MJ. 2000. The Evolution of Plant Ecophysiological Traits: Recent Advances and Future Directions: New research addresses natural selection, genetic constraints, and the adaptive evolution of plant ecophysiological traits. BioScience 50 :979-995. DOI: https://doi.org/10.1641/0006-3568(2000)050[0979:teopet]2.0.co;2

Adler PB, Salguero-Gómez R, Compagnoni A, Hsu JS, Ray-Mukherjee J, Mbeau-Ache C, Franco M. 2014. Functional traits explain variation in plant life history strategies. Proceedings of the National Academy of Sciences 111: 740-745. DOI: https://doi.org/10.1073/pnas.1315179111 
Akaike H. 1974. A new look at the statistical model identification. IEEE 19 :716-723. DOI: https://doi.org/10.1109/ TAC.1974.1100705

Ansley RJ, Boutton TW, Jacoby PW. 2007. Mesquite root distribution and water use efficiency in response to longterm soil moisture manipulations. In: Sosebee RE, Wester DB, Britton CM, McArthur ED, Kitchen SG, eds. Proceedings: Shrubland dynamics - fire and water. Proccedings RMRS-P-47. Fort Collins, CO: Department of Agriculture, Forest Service, Rocky Mountain Research Station, pp. 96-103.

Barak RS, Lichtenberger TM, Wellman-Houde A, Kramer AT, Larkin DJ. 2018. Cracking the case: Seed traits and phylogeny predict time to germination in prairie restoration species. Ecology and Evolution 8: 5551-5562. DOI: https://doi.org/10.1002/ece3.4083

Buendía-González L, Estrada-Zúñiga ME, Orozco-Villafuerte J, Cruz-Sosa F, Vernon-Carter EJ. 2012. Somatic embryogenesis of the heavy metal accumulator Prosopis laevigata. Plant Cell Tissue and Organ Culture 108: 287296. DOI: https://doi.org/10.1007/s11240-011-0042-4

Calderón G, Rzedowski J. 2001. Flora fanerogámica del Valle de México. México: Instituto de Ecología AC. y Comisión Nacional para el Conocimiento y Uso de la Biodiversidad. ISBN: 978-607-7607-36-6.

Campos CM, Ojeda RA. 1997. Dispersal and germination of Prosopis flexuosa (Fabaceae) seeds by desert mammals in Argentina. Journal of arid Environments 35: 707-714. DOI: https://doi.org/10.1006/jare.1996.0196

Contreras-Negrete G, Letelier L, Piña-Torres J, González-Rodríguez A. 2021a. Genetic structure, phylogeography and potential distribution modeling suggest a population expansion in the mesquite Prosopis laevigata since the last interglacial. Plant Systematics and Evolution 307: 22. DOI: https://doi.org/10.1007/s00606-021-01744-5

Contreras-Negrete G, Pineda-García F, Nicasio-Arzeta S, De la Barrera E, González-Rodríguez A. 2021b. Differences in germination response to temperature, salinity, and water potential among Prosopis laevigata populations are guided by the tolerance-exploitation trade-off. Flora 285: 151963. DOI: https://doi.org/10.1016/j.flora.2021.151963

Cony MA, Trione S. 1996. Germination with respect to temperature of two Argentinian Prosopis species. Journal of Arid Environments 33: 225-236.

Cony MA, Trione SO. 1998. Inter and intraspecific variability in Prosopis flexuosa and P. chilensis: seed germination under salt and moisture stress. Journal of Arid Environments 40: 307-317. DOI: https://doi.org/10.1006/jare.1998.0448

Costa-Saura JM, Martínez-Vilalta J, Trabucco A, Spano D, Mereu S. 2016. Specific leaf area and hydraulic traits explain niche segregation along an aridity gradient in Mediterranean woody species. Perspectives in Plant Ecology, Evolution and Systematics 21: 23-30. DOI: https://doi.org/10.1016/j.ppees.2016.05.001

Cuervo-Robayo AP, Téllez-Valdés O, Gómez-Albores MA, Venegas-Barrera CS, Manjarrez J, Martínez-Meyer E. 2014. An update of high-resolution monthly climate surfaces for Mexico. International Journal of Climatology 34: 2427-2437. DOI: https://doi.org/10.1002/joc.3848

De Noir F, Juárez M, Boletta P, Avila S. 2002. Ripeness and seed dispersal in a semiarid region of Argentina and their relation with some climatic factors. Foresta Veracruzana 4: 7-13

de Villalobos AE, Peláez DV. 2015. Functional responses of woody Prosopis caldenia seedlings to drought and livestock grazing in semiarid rangelands of Argentina. Arid Land Research and Management 29: 487-502. DOI: https://doi.org/10.1080/15324982.2015.1030798

Donohue K, Rubio de Casas R, Burghardt L, Kovach K, Willis CG. 2010. Germination, Postgermination Adaptation, and Species Ecological Ranges. Annual Review of Ecology, Evolution, and Systematics 41: 293-319. DOI: https:// doi.org/10.1146/annurev-ecolsys-102209-144715

ESRI [Environmental Systems Research Institute] 1999. Arcview GIS 3.3. Environmental Systems Research Institute, Redlands.

Fagg CW, Stewart JL. 1994. The value of Acacia and Prosopis in arid and semi-arid environments. Journal of Arid Environments 27: 3-25. DOI: https://doi.org/10.1006/jare.1994.1041

Fajardo A, Piper FI. 2011. Intraspecific trait variation and covariation in a widespread tree species (Nothofagus pumilio) in southern Chile. New Phytologist 189: 259-271. DOI: https://doi.org/10.1111/j.1469-8137.2010.03468.x 
Fenner M, Thompson K. 2005. The Ecology of Seeds. Cambridge: Cambridge University Press. DOI: https://doi. org/10.1017/CBO9780511614101

Flores J, Jurado E. 1998. Germination and early growth traits of 14 plant species native to northern Mexico. The Southwestern Naturalist 43: 40-46.

Flores J, Pérez-Sánchez RM, Jurado E. 2017. The combined effect of water stress and temperature on seed germination of Chihuahuan Desert species. Journal of Arid Environments 146: 95-98. DOI: https://doi.org/10.1016/j. jaridenv.2017.07.009

Flores Tena FJ. 1993. Atributos ecológicos y aprovechamiento del mezquite. Investigación y Ciencia: de la Universidad Autónoma de Aguascalientes 9: 24-30.

Galindo Almanza S, García Moya E, Wendt TL, González Cossio FV. 1992. Potencial de hibridación natural en el mesquite (Prosopis laevigata y P. glandulosa var. Torreyana, Leguminosae) de la altiplanicie de San Luis Potosi. Acta Botánica Mexicana 20. DOI: https://doi.org/10.21829/abm20.1992.660

Gardarin A, Coste F, Wagner M-H, Dürr C. 2016. How do seed and seedling traits influence germination and emergence parameters in crop species? A comparative analysis. Seed Science Research 26: 317-331. DOI: https://doi. org $/ 10.1017 / \mathrm{S} 0960258516000210$

Gogosz AM, Torres Boeger MR. 2019. Functional morphology of subtropical tree seedlings in southern Brazil. Rodriguésia 70: DOI: https://doi.org/10.1590/2175-7860201970010

Guevara A, Giordano CV, Aranibar J, Quiroga M, Villagra PE. 2010. Phenotypic plasticity of the coarse root system of Prosopis flexuosa, a phreatophyte tree, in the Monte Desert (Argentina). Plant and Soil 330: 447-464. DOI: https://doi.org/10.1007/s11104-009-0218-4

Hacke UG, Sperry JS, Pockman WT, Davis SD, McCulloh KA. 2001. Trends in wood density and structure are linked to prevention of xylem implosion by negative pressure. Oecologia 126: 457-461. DOI: https://doi.org/10.1007/ $\underline{\mathrm{s} 004420100628}$

Jacobsen A, Agenbag L, Esler K, Pratt RB, Ewers F, Davis S. 2007. Xylem density, biomechanics and anatomical traits correlate with water stress in 17 evergreen shrub species of the Mediterranean-type climate region of South Africa. Journal of Ecology 95: 171-183. DOI: https://doi.org/10.1111/j.1365-2745.2006.01186.x

Jung V, Violle C, Mondy C, Hoffmann L, Muller S. 2010. Intraspecific variability and trait-based community assembly. Journal of Ecology 98: 1134-1140. DOI: https://doi.org/10.1111/j.1365-2745.2010.01687.x

Lambers H, Poorter H. 1992. Inherent variation in growth rate between higher plants: A search for physiological causes and ecological consequences. Advances in Ecological Research 23: 187-261. DOI: https://doi.org/10.1016/ $\underline{\mathrm{S} 0065-2504(08) 60148-8}$

Larson JE, Sheley RL, Hardegree SP, Doescher PS, James JJ. 2015. Seed and seedling traits affecting critical life stage transitions and recruitment outcomes in dryland grasses. Journal of Applied Ecology 52: 199-209. DOI: https://doi.org/10.1111/1365-2664.12350

Laughlin DC, Strahan RT, Adler PB, Moore MM. 2018. Survival rates indicate that correlations between communityweighted mean traits and environments can be unreliable estimates of the adaptive value of traits. Ecology Letters 21: 411-421. DOI: https://doi.org/10.1111/ele.12914

Llanderal-Mendoza J, Gugger FP, Oyama K, Uribe-Salas D, González-Rodríguez A. 2017. Climatic determinants of acorn size and germination percentage of Quercus rugosa (Fagaceae) along a latitudinal gradient in Mexico. Botanical Sciences 95: 37-45. DOI: https://doi.org/10.17129/botsci.640

Lloret F, Casanovas C, Peñuelas J. 1999. Seedling survival of Mediterranean shrubland species in relation to root:shoot ratio, seed size and water and nitrogen use. Functional Ecology 13: 210-216. DOI: https://doi.org/10.1046/j.13652435.1999.00309.x

Majd R, Aghaie P, Kazerooni Monfared E, Alebrahim M. 2013. Evaluating of Some Treatments on Breaking seed Dormancy in Mesquite. International Journal of Agronomy and Plant Production 4: 1433-1439.

Markesteijn L, Poorter L. 2009. Seedling root morphology and biomass allocation of 62 tropical tree species in relation to drought- and shade-tolerance. Journal of Ecology 97: 311-325. DOI: https://doi.org/10.1111/j.1365-2745.2008.01466.x 
Méndez-Alonzo R, Paz H, Zuluaga RC, Rosell JA, Olson ME. 2012. Coordinated evolution of leaf and stem economics in tropical dry forest trees. Ecology 93: 2397-2406. DOI: https://doi.org/10.1890/11-1213.1

Miranda R, Oliveira M, Correia R, Almeida-Cortez J, Pompelli M. 2011. Germination of Prosopis juliflora (Sw) DC seeds after scarification treatments. Plant Species Biology 26: 186-192. DOI: https://doi.org/10.1111/j.1442-1984.2011.00324.x

Moles A, Westoby M. 2004. Seedling survival and seed size: a synthesis of the literature. . Journal of Ecology 92 : 372-383. DOI: https://doi.org/10.1111/j.0022-0477.2004.00884.x

Moles AT, Perkins SE, Laffan SW, Flores-Moreno H, Awasthy M, Tindall ML, Sack L, Pitman A, Kattge J, Aarssen LW, Anand M, Bahn M, Blonder B, Cavender-Bares J, Cornelissen JHC, Cornwell WK, Díaz S, Dickie JB, Freschet GT, Griffiths JG, Gutierrez AG, Hemmings FA, Hickler T, Hitchcock TD, Keighery M, Kleyer M, Kurokawa H, Leishman MR, Liu K, Niinemets Ü, Onipchenko V, Onoda Y, Penuelas J, Pillar VD, Reich PB, Shiodera S, Siefert A, Sosinski Jr EE, Soudzilovskaia NA, Swaine EK, Swenson NG, van Bodegom PM, Warman L, Weiher E, Wright IJ, Zhang H, Zobel M, Bonser SP. 2014. Which is a better predictor of plant traits: temperature or precipitation? Journal of Vegetation Science 25: 1167-1180. DOI: https://doi.org/10.1111/jvs.12190

Murray BR, Brown AHD, Dickman CR, Crowther MS. 2004. Geographical gradients in seed mass in relation to climate. Journal of Biogeography 31: 379-388. DOI: https://doi.org/10.1046/j.0305-0270.2003.00993.x

Nadeem M, Mollier A, Morel C, Shahid M, Aslam M, Zia-ur-Rehman M, Wahid MA, Pellerin S. 2013. Maize seedling phosphorus nutrition: Allocation of remobilized seed phosphorus reserves and external phosphorus uptake to seedling roots and shoots during early growth stages. Plant and Soil 371: 327-338.

Nemani RR, Keeling CD, Hashimoto H, Jolly WM, Piper SC, Tucker CJ, Myneni RB, Running SW. 2003. Climatedriven increases in global terrestrial net primary production from 1982 to 1999. Science 300: 1560-1563. DOI: hppts://doi.org/ 10.1126/science.1082750

Niinemets Ü. 2001. Global-scale climatic controls of leaf dry mass per area, density, and thickness in trees and shrubs. Ecology 82: 453-469. DOI: https://doi.org/10.2307/2679872

Ortega-Baes P, de Viana M, Sühring S. 2002. Germination in Prosopis ferox seeds: Effects of mechanical, chemical and biological scarificators. Journal of Arid Environments 50: 185-189. DOI: https://doi.org/10.1006/jare.2001.0859

Palacios R. 2006. Los Mezquites Mexicanos: Biodiversidad y Distribución Geográfica. Boletín de la Sociedad Argentina de Botánica 41: 99-121.

Palacios RA, Hernández FM, Jiménez ME, Tirado TD. 2016. Potential distribution of Prosopis laevigata (Humb. etBonpl. ex Willd) M. C. Johnston based on an ecological niche model. Revista Mexicana de Ciencias forestales 7: 35-46.

Pasiecznik NM, Felker P, Harris PJC, Harsh LN, Cruz G, Tewari JC, Cadoret K, Maldonado LJ. 2001. The Prosopis juliflora-Prosopis pallida complex: A monograph. UK, Coventry: HDRA. ISBN: 0-905343301.

Pérez-Harguindeguy N, Díaz S, Garnier E, Lavorel S, Poorter H, Jaureguiberry P, Bret-Harte MS, Cornwell WK, Craine J, Gurvich D, Urcelay C, Veneklaas E, Reich P, Poorter L, Wright IJ, Ray P, Enrico L, Pausas JG, de Vos, Buchmann N, Funes G, Quétier F, Hodgson JG, Thompson K, Morgan HD, ter Steege H, van der Heijden MGA, Sack L, Blonder B, Poschlod P, Vaieretti MV, Conti G, Staver AC, Aquino S, Cornelissen JHC. 2013. New handbook for standardised measurement of plant functional traits worldwide. Australian Journal of Botany 61: 167234. DOI: https://doi.org/10.1071/BT12225

Pérez-Sánchez RM, Jurado E, Chapa-Vargas L, Flores J. 2011. Seed germination of Southern Chihuahuan Desert plants in response to elevated temperatures. Journal of Arid Environments 75: 978-980. DOI: https://doi. org/10.1016/j.jaridenv.2011.04.020

Petit C, Thompson JD. 1998. Phenotypic selection and population differentiation in relation to habitat heterogeneity in Arrhenatherum elatius (Poaceae). Journal of Ecology 86: 829-840. DOI: https://doi.org/10.1046/j.13652745.1998.8650829.x

Pineda-García F, Paz H, Meinzer FC, Angeles G. 2016. Exploiting water versus tolerating drought: water-use strategies of trees in a secondary successional tropical dry forest. Tree Physiology 36: 208-217. DOI: https://doi. org/10.1093/treephys/tpv124

Pineda-García F, Paz H, Tinoco-Ojanguren C. 2011. Morphological and physiological differentiation of seedlings 
between dry and wet habitats in a tropical dry forest. Plant, cell \& environment 34: 1536-1547. DOI: https://doi. org/10.1111/j.1365-3040.2011.02351.x

Poorter H, Niklas KJ, Reich PB, Oleksyn J, Poot P, Mommer L. 2012. Biomass allocation to leaves, stems and roots: meta-analyses of interspecific variation and environmental control. New Phytologist 193: 30-50. DOI: https://doi. org/10.1111/j.1469-8137.2011.03952.x

Ramírez-Arriaga E, Prámparo MB, Martínez-Hernández E. 2006. Palynology of the Paleogene Cuayuca Formation (Stratotype Sections), Southern Mexico: chronostratigraphical and palaeoecological implications. Review of Palaeobotany and Palynology 141: 259-275.

Reich PB. 2014. The world-wide 'fast-slow' plant economics spectrum: a traits manifesto. Journal of Ecology 102: 275-301. DOI: https://doi.org/10.1111/1365-2745.12211

Reich P, Ellsworth D, Walters M, Vose J, Gresham C, Volin J, Bowman W. 1999. Generality of leaf trait relationships: A test across six biomes. Ecology 80: 1955-1969. DOI: https://doi.org/10.1890/0012-9658(1999)080[1955:GOL TRA]2.0.CO;2

Reich PB, Walters MB, Tjoelker MG, Vanderklein D, Buschena C. 1998. Photosynthesis and respiration rates depend on leaf and root morphology and nitrogen concentration in nine boreal tree species differing in relative growth rate. Functional Ecology 12: 395-405. DOI: https://doi.org/10.1046/j.1365-2435.1998.00209.x

Reich P, Wright I, Cavender-Bares J, Craine J, Oleksyn J, Westoby M, Walters M. 2003. The evolution of plant functional variation: traits, spectra, and strategies. International Journal of Plant Sciences 164: S143-S164. DOI: https://doi.org/10.1086/374368

Rzedowski J. 1988. Análisis de la distribución geográfica del complejo Prosopis (Leguminosae, Mimosoideae) en Norteamérica. Acta Botanica Mexicana 3: 7-19. DOI: https://doi.org/10.21829/abm3.1988.566

Salazar PC, Navarro-Cerrillo R, Cruz G, Grados N, Villar R. 2019. Variability in growth and biomass allocation and the phenotypic plasticity of seven Prosopis pallida populations in response to water availability. Trees 33: 14091422. DOI: https://doi.org/10.1007/s00468-019-01868-9

Salazar PC, Navarro-Cerrillo R, Cruz G, Villar R. 2018. Intraspecific leaf functional trait variability of eight Prosopis pallida tree populations along a climatic gradient of the dry forests of northern Peru. Journal of Arid Environments 152: 12-20. DOI: https://doi.org/10.1016/j.jaridenv.2018.01.010

Suding K, Lavorel S, Chapin Iii FS, Cornelissen J, Diaz S, Garnier E, Goldberg D, Hooper D, Jackson S, Navas M-L. 2008. Scaling environmental change through the community-level: A trait-based response-and-effect framework for plants. Global Change Biology 14: 1125-1140. DOI: https://doi.org/10.1111/j.1365-2486.2008.01557.x

Tilman D. 1985. The Resource-Ratio Hypothesis of Plant Succession. The American Naturalist 125: 827-852.

Trabucco A, Zomer RJ. 2010. Global Soil Water Balance Geospatial Database. Available from CGIAR Consortium for Spatial Information. https://cgiarcsi.community (accesed July 15, 2020).

Vilela A, Ravetta D. 2001. The effect of seed scarification and soil-media on germination, growth, storage, and survival of seedlings of five species of Prosopis L. (Mimosaceae). Journal of Arid Environments 48: 171-184. DOI: https://doi.org/10.1006/jare.2000.0735

Villagra P. 1995. Temperature effects on germination of Prosopis argentina and P. alpataco (Fabaceae, Mimosoideae). Seed Science and Technology 23: 639-646.

Westoby M. 1998. A leaf-height-seed (LHS) plant ecology strategy scheme. Plant and Soil 199: 213-227. DOI: https://doi.org/10.1023/A:1004327224729

Wright IJ, Westoby M. 1999. Differences in seedling growth behaviour among species: trait correlations across species, and trait shifts along nutrient compared to rainfall gradients. Journal of Ecology 87: 85-97. DOI: https://doi. org/10.1046/j.1365-2745.1999.00330.x

Editor de Sección: Joel Flores

Authors contributions: FHM, conception of research, field and laboratory work, statistical analyses, manuscript preparation, review and comments; GCN, conception of research, field and laboratory work, review and comments; RAR, statistical analyses, review and comments; FPG, review and comments, funding acquisition; AGR, statistical analyses, manuscript preparation, funding acquisition, project supervision. 